\title{
AN EVALUATION OF GROSS INLAND ENERGY CONSUMPTION OF SIX CENTRAL EUROPEAN COUNTRIES
}

\author{
Róbert Magda \\ Szent István University, Gödöllő, Hungary \\ North-West University, Vanderbijlpark, South Africa \\ Norbert Bozsik \\ Eszterházy Károly University, Eger, Hungary \\ Natanya Meyer \\ North-West University, Vanderbijlpark, South Africa
}

\begin{abstract}
The study provides a comprehensive overview of the current structure and utilization of energy production of six Central European countries (Poland, Czech Republic, Slovakia, Bulgaria, Hungary and Romania) focusing on the dependence on energy imports. The purpose of the article was to analyse the gross inland energy consumption of these six countries and to examine the relationship between renewable energy and non-renewable energy sources. A comparative time series analysis method using data from 2010 to 2016 was utilized. In addition, partial correlation analysis under control variables to determine whether the relationship calculated in the correlation matrix exists or not was applied. Results indicated that in the European Union, the renewables have mainly replaced nuclear energy. A combination of renewables and natural gas replaced the coal in Poland, Czech Republic, Slovakia and Bulgaria. Findings were inconclusive to prove this in Hungary and Romania. The energy production structure of the six Central European countries varies due to the differences in natural endowments. However, the results showed that the renewables mainly replaced coal.
\end{abstract}

Keywords: Central European countries, correlation matrix, energy consumption, Sankey diagram

DOI: http://dx.doi.org/10.15549/jeecar.v6i2.291

\section{INTRODUCTION}

In the recent decades, the world economic growth was significant due to the low cost of natural resources used for production and transportation. Today, only a few regions in the world are producing fossil fuels. The political situation in most of these regions is unstable. 
Therefore, these regions are fairly uncertain sources of energy (Harangi-Rakos et al., 2017). With the growth of the world's population, the energy consumption is significantly increasing, mainly in the fast growing Asian and African regions (British Patrol, 2018). In addition to the growing production and the change in lifestyles, especially in developed countries, energy demand also increased (Fodor, 2012). The improvement of energy efficiency reduces the growing demand for energy (Popp et al., 2018a; Popp et al., 2018b), however renewable energy has become a key issue to partially replace the fossil energy. The role of renewable energy is significant even if the renewables are often available in smaller quantities, the production cannot be regulated, and some of them depend on the weather conditions. The purpose of the article was therefore, to analyse the gross inland energy consumption of these six countries and to examine the relationship between renewable energy and non-renewable energy sources.

\section{REVIEW OF LITERATURE}

The potential for renewable energy resources is enormous because they can exponentially exceed the world's energy demand; therefore, these types of resources will have a significant share in the future global energy portfolio (Ellabban et al., 2014). In the future, biomass can be considered as the best option and has the largest potential, which meets these requirements and could insure fuel supply (Demirbas et al., 2009). A number of renewable energy technologies are available at different stages of the development cycle. Hydropower and bioenergy are the main sources of energy worldwide. Other options are technically proven and available on commercial terms, but still occupy only a fraction of their potential markets (International Energy Agency 2011; Doner, 2007; Wiuff et al., 2006).

Hydropower, wind, solar, and biomass energy are even more expensive than fossil-based power generation. However, due to steadily declining reserves of fossils and rising energy prices, it is increasingly worthwhile to switch to renewable energy sources (Popp, 2013). The renewable energy growth around the world continues to be driven by a combination of targeted public policy and advances in energy technologies. The policy support for renewable energy focuses primarily on power generation, with support for renewable technologies lagging in the heating and cooling as well as transport sectors (REN21, 2018).

The utilization of renewable energy sources has an increasing role in the EU's climate and energy policy. By using more renewables to meet its energy needs, the European Union lowers its dependence on imported fossil fuels, which makes its energy production more sustainable. Influenced by economic and environmental interests, the European Union committed itself to increase the utilization of renewable energy sources at the end of the 1990s. The Energy Policy White Paper issued by the European Commission initiated a common Renewable Energy Strategy and set up an Action Plan in 1997. The indicative objective was $12 \%$ share for the contribution by renewable sources of energy to the European Union's gross inland energy consumption by 2010 (European Commission, 1997). Recognizing the growing dependence on imports, the European Commission defined the objectives of energy policy in the Green Paper in 2006. Three key energy policy objectives were identified: improved competitiveness, security of supply, and protection of the environment (Commission of the European Communities, 2006). The Directive 2009/28/EC established an overall policy for the production and promotion of energy from renewable sources in the EU. The directive set a binding target of $20 \%$ final energy consumption from renewable sources by 2020 to be achieved through the attainment of individual national targets. Each EU country must have shown what actions they would intend to take to meet their renewables targets (including sectorial targets for electricity, heating and cooling, and transport). The countries must also ensure that at least $10 \%$ of their transport fuels come from renewable sources by 2020 .

The European Council set even more ambitious goals by increasing commitments by 2030. The aim was to promote the EU to achieve a more competitive, secure and sustainable energy system. The EU countries agreed on a new renewable energy target of at least $27 \%$ of EU's final energy consumption and a $40 \%$ cut in 
greenhouse gas emissions compared to 1990 levels.

A target for an improvement in energy efficiency at EU level was set at a minimum of $27 \%$ by 2030 . The European Commission aimed to increase the proportion of renewables in gross final energy consumption between 55\% and $75 \%$ by 2050 . This, along with energy efficiency, is considered critical in any model that could be adopted (Hernández et al., 2017).

In comparison with traditional energy production, renewable energy production is not yet competitive under current market conditions, due to the high technology investment costs and environmental effects of externalities not being adequately reflected in market prices. Therefore, support is needed for renewable energy production (Fodor, 2012). In addition, the post-Soviet countries have been highly dependent on fossil energy imports from Russia. This dependency was determined by the east-west orientation of its oil and gas infrastructure (Jurcova, 2017). The development of renewable energy is important from the viewpoint of lowering the cost of imported energy borne by Central European countries. In addition, it would help to achieve the aims of reducing $\mathrm{CO}_{2}$ emissions (Piwowar et al., 2017,. Many illusions are related to the widespread use of renewable energy resources, however the low emission of harmful byproducts is making them attractive. This is true for the application of biomass which is neutral to $\mathrm{CO}_{2}$ emissions in regard to the whole production cycle (Szabo \& Kiss, 2014).

The EU policy on energy aims to ensure security of energy supply in the member states, to promote energy efficiency and energy saving, as well as to increase the share of renewable energy. Solidarity among the member states is fundamental. However, each country is responsible for its own energy security. The spread of renewables may be impeded by the availability of fossil resources within a country (e.g. UK, Poland). The factors that provide the framework for countries are as follows: different international obligations, differences in planning/licensing cultures, and public awareness concerning renewables and/or technical differences (Reiche \& Bechberger, 2004).

\section{RESEARCH METHODOLOGY}

In this article, the gross inland energy consumption of six Central European countries was analyzed. The gross inland energy consumption represents the quantity of energy needed to satisfy inland consumption of the geographical entity. In a narrow sense, it represents the sum of primary energy production and net import (import-export). In a broad sense, it is supplemented with recovered products, variations of stocks, bunkers and direct use. The data for analysis were sourced from the database of the European Commission Eurostat and the International Renewable Energy Agency (IRENA) for the period from 2010 to 2016. In the study, the comparative time series analysis method was used. The purpose of the article was to analyze the gross inland energy consumption of the six Central European countries and to examine the relationship between renewable energy and non-renewable energy sources. In the course of the analysis, the aim was to determine which non-renewable energy type was replaced by the renewables in the six Central European countries. The substitution of energy sources was analyzed using correlation matrices and was evaluated at 0.05 significance. In addition, partial correlation analysis under control variables to determine whether the relationship calculated in the correlation matrix exists or not were applied. The evaluation was performed by using IBM SPSS Statistics 20, GRETL 2018a, and MS-Office Excel 2016.

\section{RESULT AND DISCUSSION}

\section{Poland's energy consumption}

For the period 2010 to 2016, Poland's annual average primary energy production was 66 thousand Kilo Tonne Oil Equivalent (ktoe). Black and brown coal were the main sources of energy production, accounting for $80 \%$ of total primary production. Poland was Europe's largest coal producer with 75 million tons per year. In 2016, Poland's import energy consumption was 50.1 thousand ktoe. The oil share of energy imports was $64 \%$, gas was $24 \%$ and coal $10 \%$. In international comparison, Poland's 30\% import 
energy dependency was low and Russia was its largest supplier. Poland's energy exports amounted to 20 thousand ktoe in 2016. Similar to domestic production, coal was also dominant in exports with a $50 \%$ share. The country's gross energy consumption decreased by $1.4 \%$ between
2010 and 2016 and amounted to 99 thousand ktoe in 2016. Coal was dominant in the gross inland energy consumption with a share of $49 \%$, $27 \%$ came from oil, $15 \%$ from natural gas and $9 \%$ from renewable energy (Figure 1).

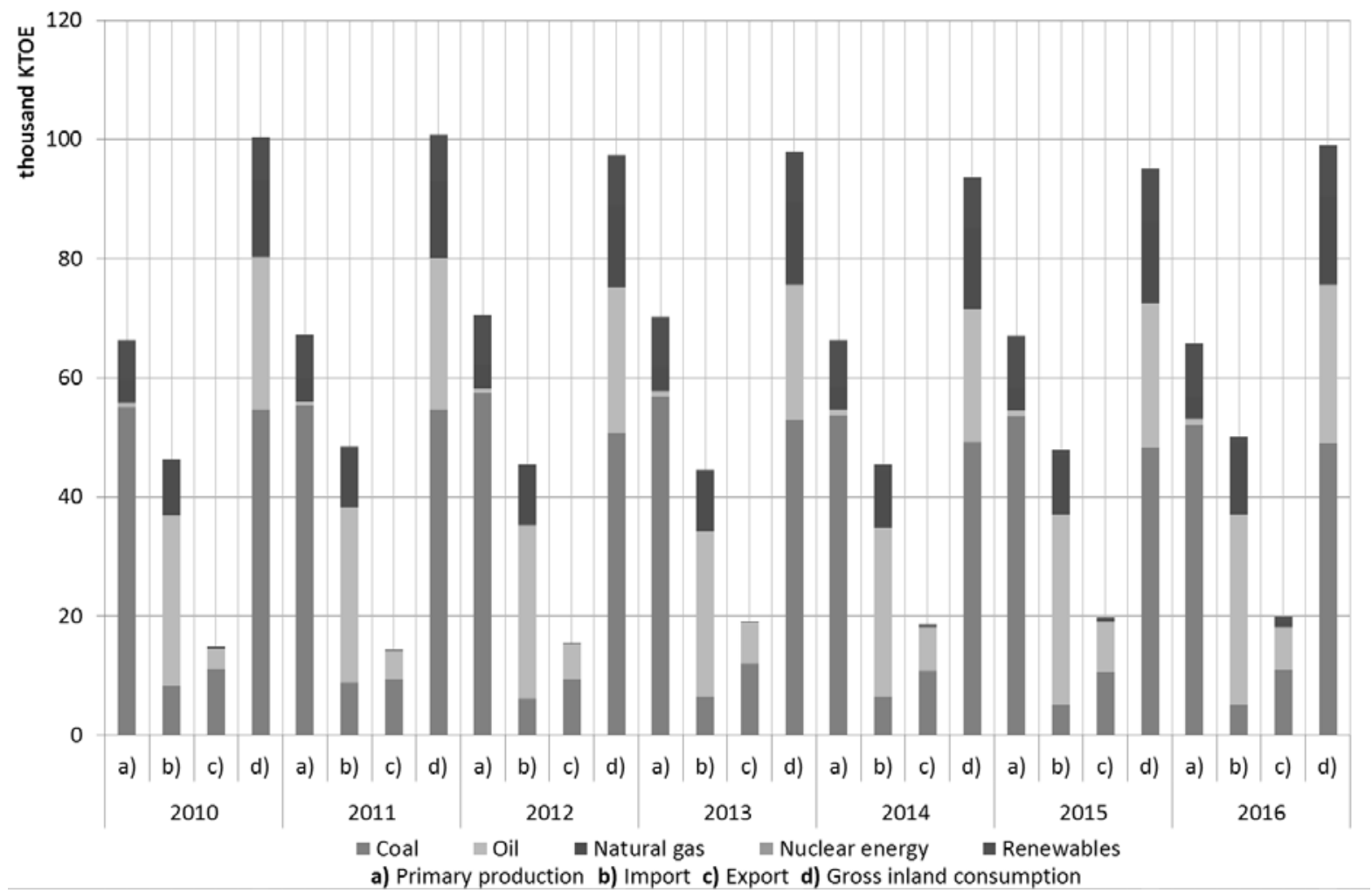

Figure 1. Development of Poland's energy consumption (thousand ktoe)

Source: Compilation based on Eurostat database (2018)

In addition, Poland's gross renewable energy supply was 8.8 thousand ktoe in 2016. Biomass accounted for $75 \%$ and wind energy for $12 \%$ of the total. $14.7 \%$ of cooling and heating, $13.3 \%$ of electricity and $3.9 \%$ of transportation were generated from renewable sources.

\section{Energy consumption of Czech Republic}

As can be seen from Figure 2, in 2016, the primary energy production of the Czech Republic amounted to 26.8 thousand ktoe, which was a $15 \%$ decrease from 2010. Coal was the main source of energy production, accounting for $60 \%$ of total primary production, while nuclear was $23 \%$ and renewables $16 \%$. In 2016, Czech Republic import energy consumption was 20.3 ktoe. The oil share of energy imports was 50\%, gas was 33\% and coal $15 \%$. In international comparison, Czech Republic's 32\% import energy dependency was lower than the average of the European Union. It imports coal mainly from Poland and oil and natural gas from Russia. The Czech Republic energy exports amounted to 5.8 thousand ktoe in 2016. Similar to domestic production, coal was also dominant in exports with a 55\% share and crude oil had a 38\% share. The Czech Republics' gross energy consumption decreased by $8 \%$ between 2010 and 2016 and amounted to 42.4 thousand ktoe in 2016. Coal represented $40 \%$ of the gross energy consumption, oil was second with $19 \%$ share, gas had a $17 \%$ share, 
nuclear energy had a $14 \%$ share and renewable energy had a $10 \%$ share.

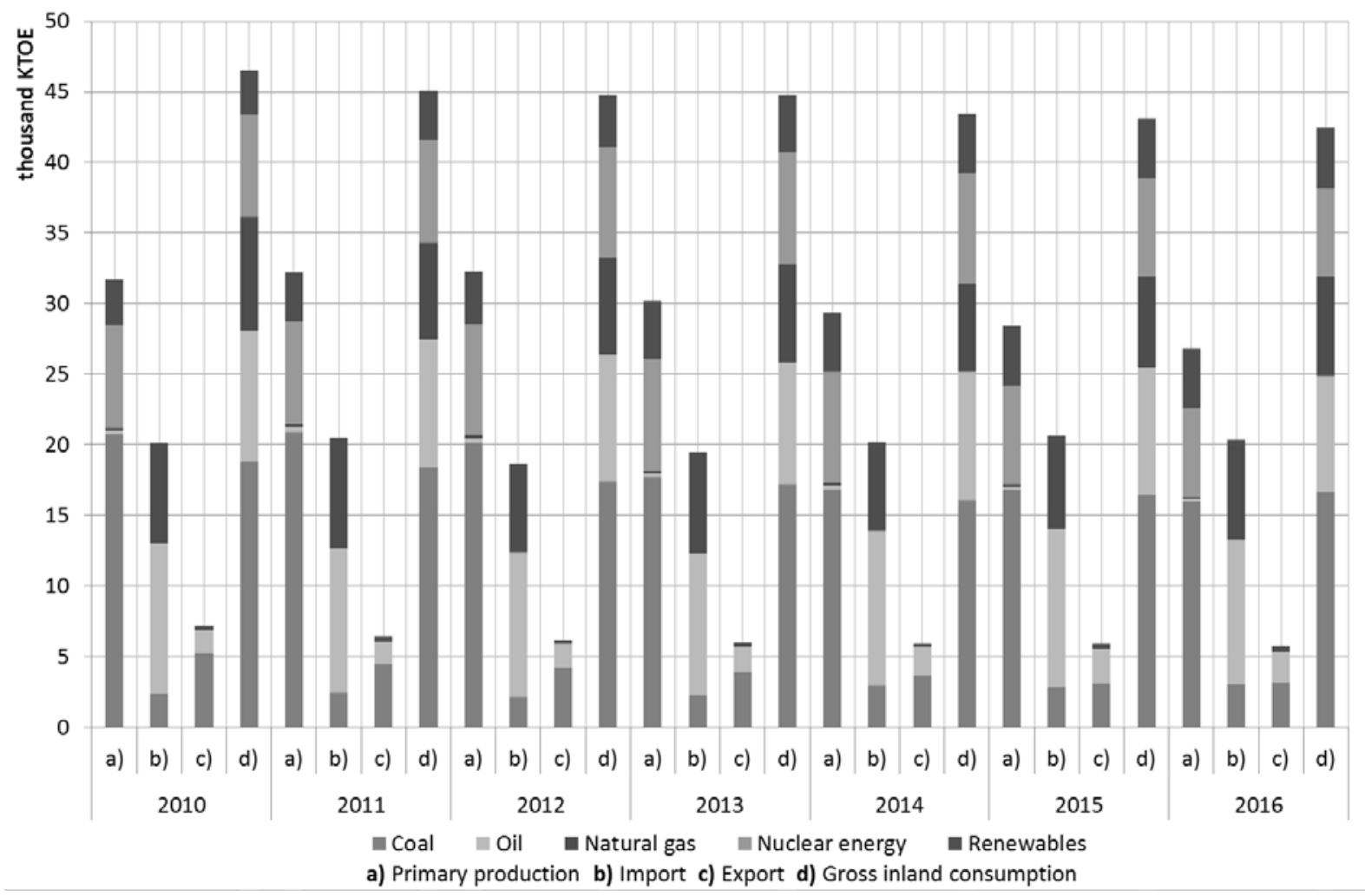

Figure 2. Development of Czech Republic's energy consumption (thousand ktoe)

Source: Compilation based on Eurostat database (2018)

As also noticed from Table 2, the Czech Republics' gross renewable energy supply was 4.3 thousand ktoe in 2016, an increase of 38\% from 2010. Biomass accounted for $67 \%$ and biogas for $14 \%$ of the total. $19.8 \%$ of cooling and heating, $6.4 \%$ of transport and $3.6 \%$ of electricity were generated from renewable sources.

\section{Slovakia's energy consumption}

Between 2010 and 2016, Slovakia's primary energy production increased by 3.8\% to reach 6 thousand ktoe. Nuclear power was the main source of energy production, accounting for $64 \%$ of the total usage, while renewables represented only 27\%. In 2016, Slovakia's import energy consumption amounted to 13.8 ktoe. The oil share of energy imports was $53 \%$, gas was $26 \%$ and coal was $20 \%$. Import energy came primarily from Russia (oil, natural gas) and from Czech Republic (coal). The country's 59\% import energy dependency was higher than the average level of the European Union. Slovakia's energy export amounted to 4.3 thousand ktoe in 2016, of which the oil share was $96 \%$ (mainly transit). Gross energy consumption of Slovakia fell from 17.7 ktoe to 16.1 ktoe between 2010 and 2016 . Noticeable from these figures, Slovakia's gross energy consumption was balanced. In 2016, natural gas and nuclear energy were dominant in the gross inland energy consumption with a share of $24 \%$ each, $22 \%$ came from oil, $20 \%$ from coal and 10\% from renewable energy (Figure 3).

Slovakia's gross renewable energy supply was 1.6 thousand ktoe in 2016. Biomass accounted for $52 \%$, hydropower for $24 \%$, biogas for $10 \%$ and biodiesel for $8 \%$ of the total. $22.5 \%$ of electricity, $9.9 \%$ of cooling and heating and $7.5 \%$ of transport were generated from renewable sources. 


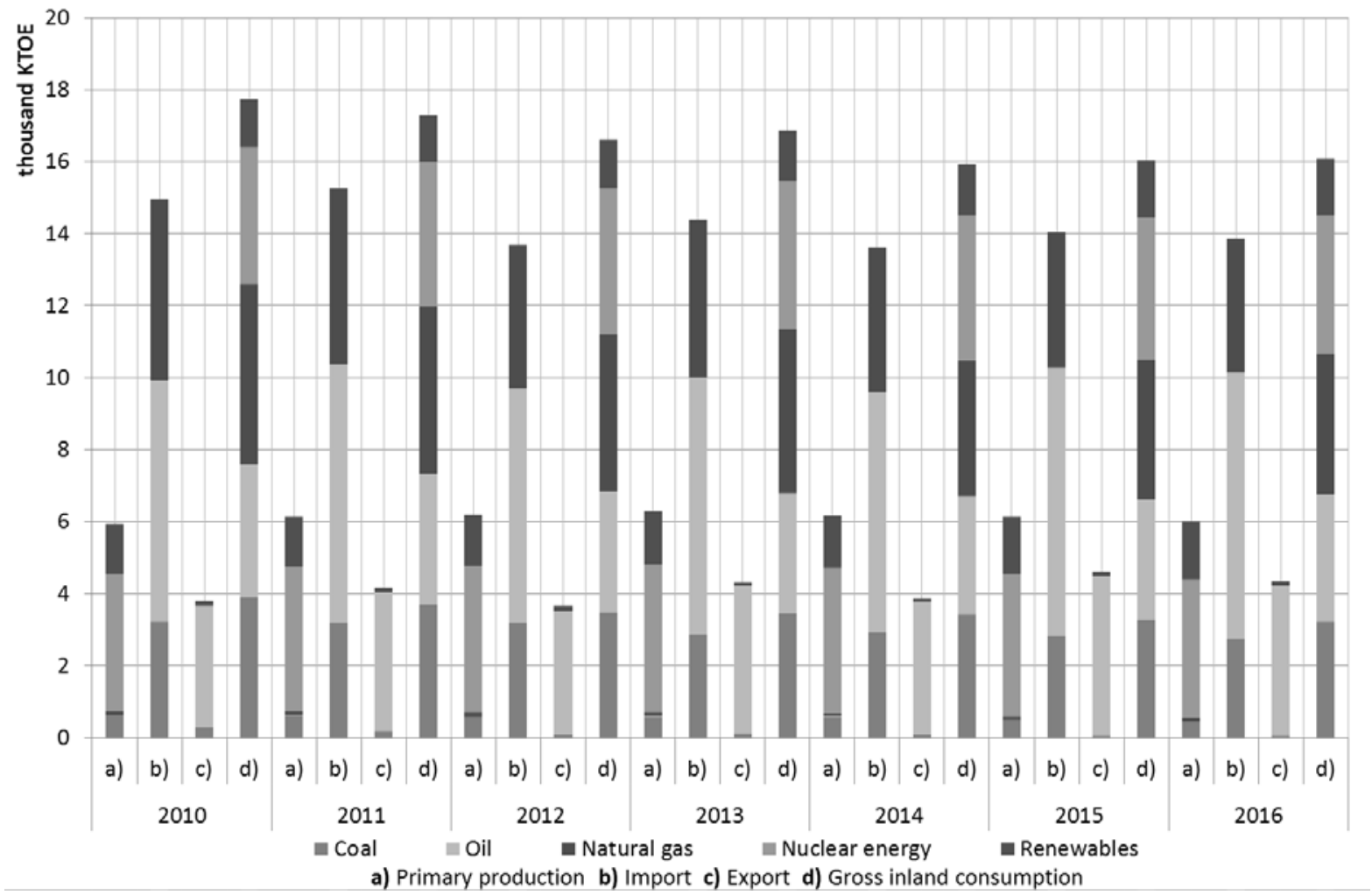

Figure 3. Development of Slovakia's energy consumption (thousand ktoe)

Source: Compilation based on Eurostat database (2018)

\section{Hungary's energy consumption}

Between 2010 and 2016, Hungary's primary energy production decreased slightly by $3.8 \%$ to reach 11.2 thousand ktoe. Nuclear energy was the main source of energy production, accounting for $37 \%$ of the total primary production in 2016. Renewables were the second highest contributor with $28 \%$, while coal and natural gas had a $13 \%$ share and oil $9 \%$. Hungary's import energy consumption was 17.8 thousand ktoe, which by far exceeded their domestic production. The energy imports showed a drastic movement during the seven years. The oil and the natural gas were dominant in the energy imports of Hungary, with a $51 \%$ and $40 \%$ share. Hungary's $55 \%$ import energy dependency was average compared to the European Union level. The Hungarian energy export was 4.6 ktoe, with a $58 \%$ oil share in 2016. The country's gross energy consumption decreased by $5.7 \%$ between 2010 and 2016 and amounted to 24.5 thousand ktoe in 2016. Gas had a 33\% share of the gross energy consumption, oil had a $29 \%$ share, nuclear energy $17 \%$, renewables $12 \%$ and coal $9 \%$ (Figure 4). 


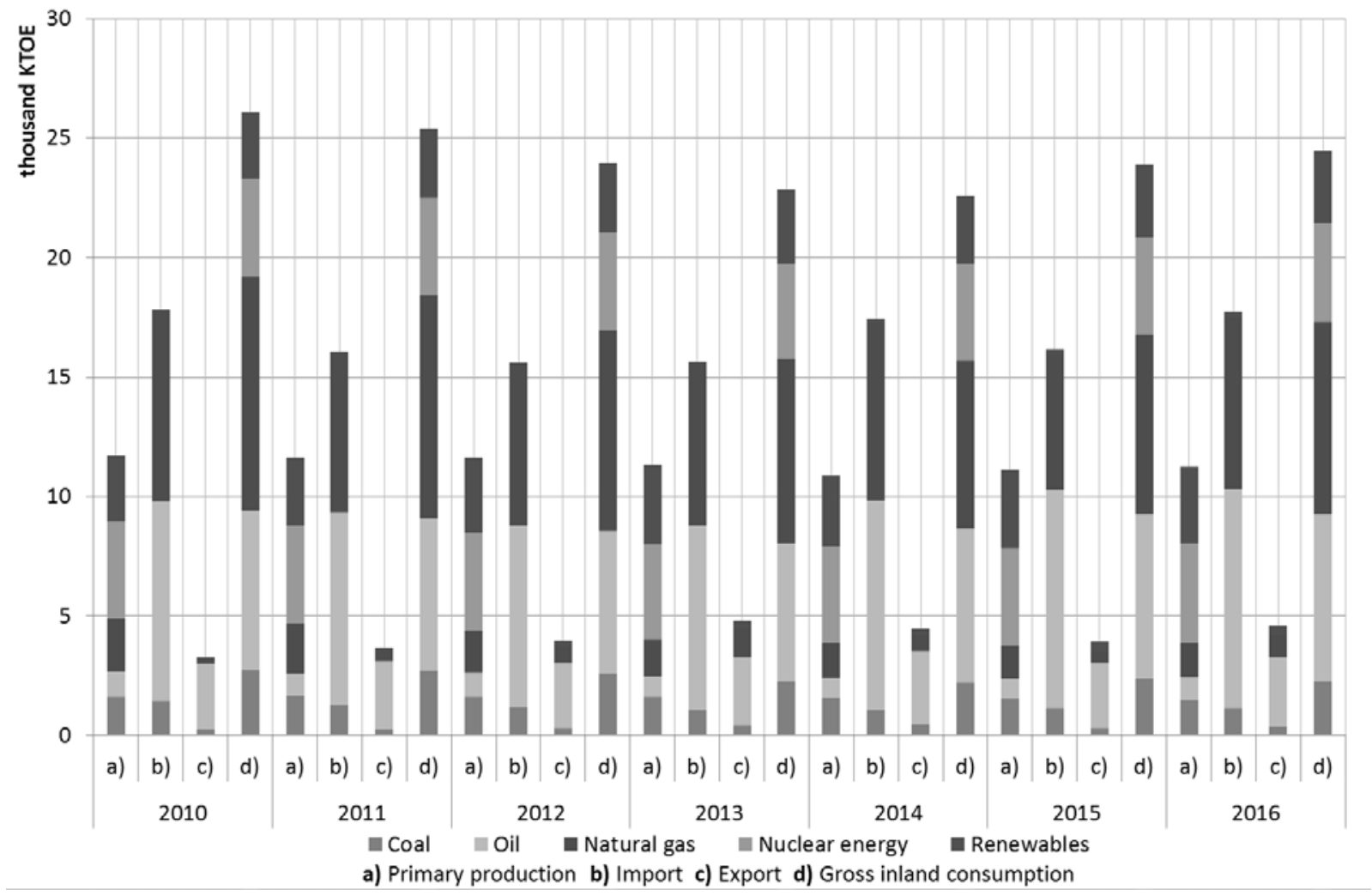

Figure 4. Development of Hungary's energy consumption (thousand ktoe)

Source: Compilation based on Eurostat database (2018)

Hungary's gross renewable energy supply was 3.0 thousand ktoe in 2016. Biomass accounted for $80 \%$, biodiesel and geothermal for $4 \%$, biogas for $3 \%$, municipal waste for $3 \%$, biogas oil for $2 \%$ and wind energy for $2 \% .20 .9 \%$ of cooling and heating, $7.4 \%$ of transport and $7.2 \%$ of electricity were generated from renewable sources.

\section{Romania's energy consumption}

Considering Figure 5, between 2010 and 2016, Romania's primary energy production decreased by $10 \%$ to reach 25 thousand ktoe. Romania was the largest oil and gas producer in Central and Eastern Europe. Natural gas accounted for 31\% of the primary energy production in 2016, renewables for $24 \%$, coal for $17 \%$, oil for $16 \%$ and nuclear energy had a $12 \%$ share. Romania's import energy consumption was 13.1 ktoe in 2016 , with an $80 \%$ oil share. Romania's $22 \%$ import energy dependency was significantly lower than average compared to the European Union level. Romania's energy export was 5.4 thousand ktoe in 2016, with 98\% crude oil share. The country's gross energy consumption decreased by $10 \%$ between 2010 and 2016 and amounted to 32.7 ktoe in 2016. Oil and natural gas represented $28 \%$ each of the gross energy consumption, renewable energy accounted for $18 \%$, coal had a $17 \%$ share and nuclear energy $9 \%$. 


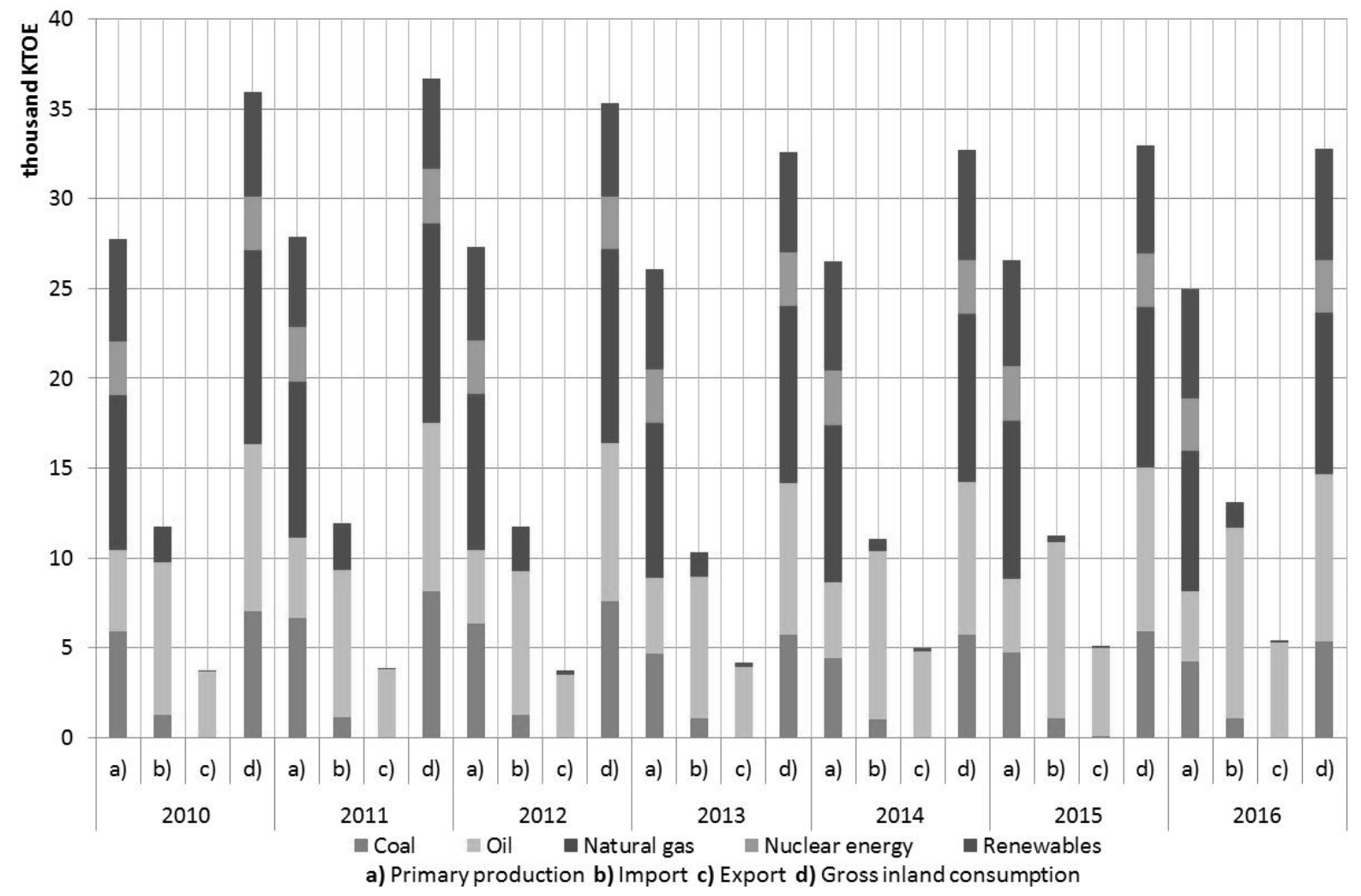

Figure 5. Development of Romania's energy consumption (thousand ktoe)

Source: Compilation based on Eurostat database (2018)

Romania's gross renewable energy supply increased by $5.6 \%$ between 2010 and 2016 to reach 6.2 thousand ktoe in 2016. Biomass accounted for $58 \%$, hydropower for $25 \%$ and wind energy for $9 \%$ of the total. $42.7 \%$ of electricity, $26.9 \%$ of cooling and heating and $6.2 \%$ of transport were generated from renewable sources.

\section{Bulgaria's energy consumption}

Between 2010 and 2016, Bulgaria's primary energy production increased by $7 \%$ to reach 11.2 thousand ktoe. Coal was the main source of energy production, accounting for $45 \%$ of the total primary production. Nuclear energy was the second highest contributor with $36 \%$, while renewables had a $17 \%$ share. The country's import energy consumption was 12.1 thousand ktoe, which is slightly above the primary production. The oil share of energy imports was $72 \%$ and natural gas 21\%. Bulgaria's 38\% energy dependency was relatively low compared to the average level of the European Union. Bulgaria's energy export amounted to 4.8 thousand ktoe in 2016 , with a $97 \%$ crude oil share. Gross energy consumption of Bulgaria reached 18.6 thousand ktoe in 2016. The country's gross energy consumption was balanced. Coal was dominant in the gross inland energy consumption with a share of $31 \%, 23 \%$ came from oil, $22 \%$ from nuclear energy, $14 \%$ from natural gas and 10\% from renewable energy (Figure 6).

Bulgaria's gross renewable energy supply increased by 34\% between 2010 and 2016 to reach 1.9 thousand ktoe in 2016. Biomass accounted for 54\%, hydropower for $17 \%$, biodiesel for $7 \%$, wind energy for $6 \%$ and photovoltaic energy (solar panels) for $6 \%$ of the total. 30\% of cooling and heating $19.2 \%$ of electricity and $7.3 \%$ of transport were generated from renewable sources. 


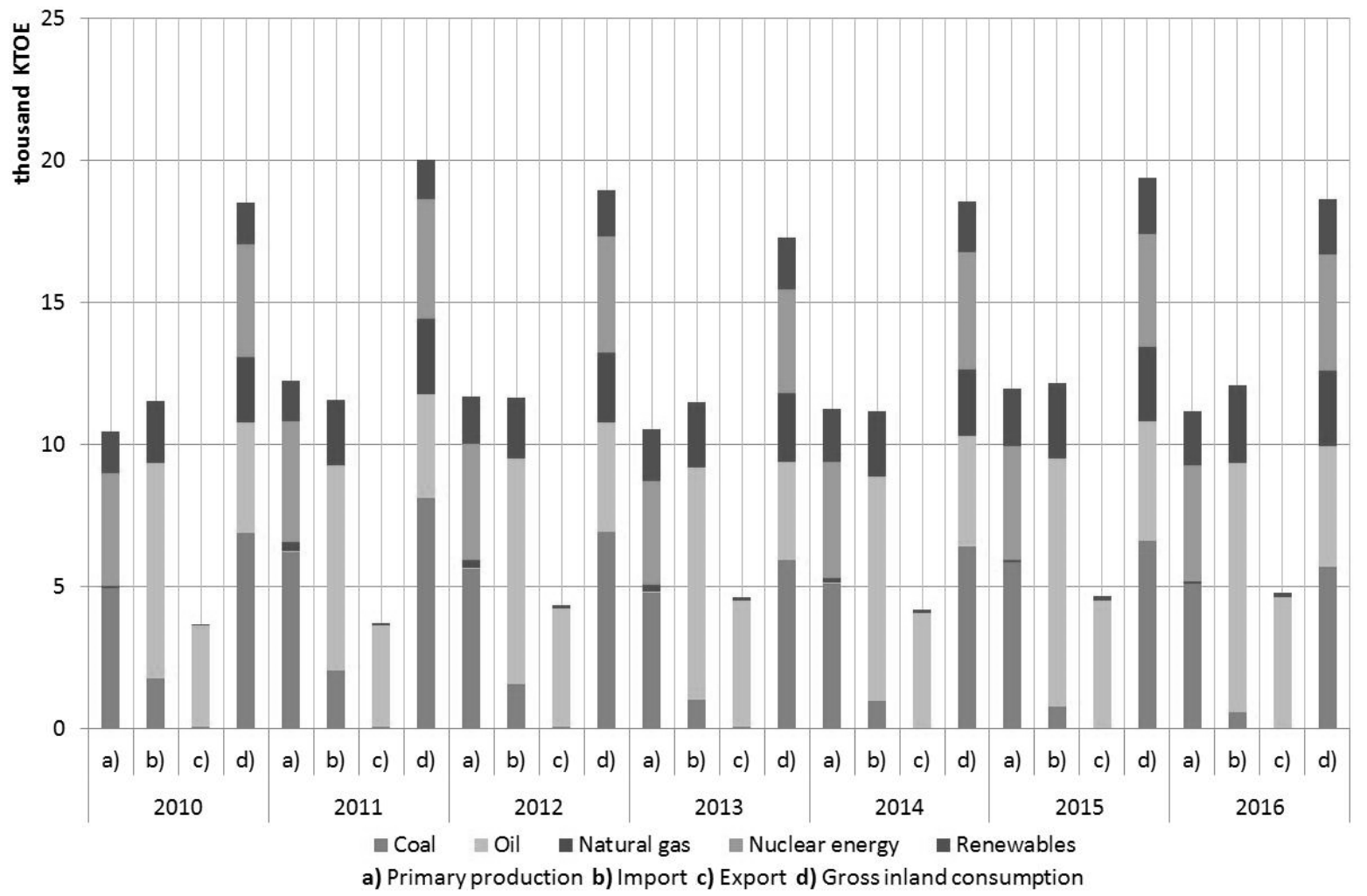

Figure 6. Development of Bulgaria's energy consumption (thousand ktoe)

Source: Compilation based on Eurostat database (2018)

Evaluation of relationship between nonrenewable energy and renewables

For the European Union as a whole, the analysis of the relationship between renewables and non-renewable energy sources showed the following results. The values of the correlation matrix (Table 1) showed that the growth of renewable energy was due to the decrease of nuclear energy (-0.9635), coal (-0.7692) and oil $(-0.7733)$. Natural gas proved to be nonsignificant at the 5\% level (95\% confidence interval). The partial correlation calculation based on control variables showed that the relation between renewables and coal, as well as renewables and oil cannot be detected. However, the relation between renewables and nuclear energy can be detected. It can be stated that in the European Union the renewables have replaced mainly the nuclear energy.

In the case of Poland, renewable energy was in negative correlation with coal $(-0.8547)$ and in positive correlation with natural gas $(+0.7826)$. Oil also proved to be non-significant at the $5 \%$ level. Poland didn't consume nuclear energy.
The partial correlation calculation showed that the negative correlation decreased between the renewables and coal when natural gas was the control variable. Therefore, the natural gas consumption affects the renewables-coal relation. However, to what extent renewables replace coal cannot be detected. Based on the analysis, it can be concluded that both natural gas and renewables replaced coal in Poland.

In the case of the Czech Republic, the situation is clear regarding the relation between renewables and non-renewable energy sources. Only the renewables-coal relation was relevant. The other three non-renewable energy types also proved to be non-significant. It was confirmed by the partial correlation test, in the case where oil, natural gas and nuclear energy were the control variables. In the Czech Republic, renewables replaced coal. In the case of Slovakia, the renewables were in negative correlation with coal (-0.8659) and with natural gas (-0.7719), which was proved only for coal by partial correlation calculation (but only 
partially). In Slovakia, renewables replaced mainly coal during the examined period.

Hungary was the only country among the four, where the renewables did not show significant correlation with any non-renewable resource. The highest correlation value (0.5800 ) was for coal, however the replacement of renewables for coal was not proven. In the case of Hungary, none of the non-renewable energy types could be detected to have been replaced by the renewables. In the case of Romania, the renewables were in negative correlation with coal $(-0.8486)$ and with natural gas $(-0.8128)$. However, it was not proven by partial correlation calculation. In the case of this country, it could not be detected which nonrenewable energy types were replaced by the renewables, but certainly not by the crude oil. In the case of Bulgaria, renewables showed significant linear correlation with coal (-0.8089). It was confirmed by the partial correlation test for the three control variables (oil, natural gas and nuclear energy). In Bulgaria, renewables basically replaced coal.

Table 1. Correlation matrix of replacement of non-renewable energies for renewables

\begin{tabular}{|l|c|c|c|c|c|c|c|}
\hline $\begin{array}{l}\text { Energy } \\
\text { carrier }\end{array}$ & Poland & $\begin{array}{l}\text { Czech } \\
\text { Republic }\end{array}$ & Slovakia & Hungary & Romania & Bulgaria & EU-28 \\
\hline Coal & $-0,8547$ & $-0,9467$ & $-0,8659$ & $-0,5800$ & $-0,8486$ & $-0,8089$ & $-0,7692$ \\
\hline Oil & $-0,3778$ & $-0,6256$ & $-0,3999$ & $-0,2838$ & 0,0006 & 0,5292 & $-0,7733$ \\
\hline Natural gas & $+0,7826$ & $-0,7115$ & $-0,7719$ & $-0,5163$ & $-0,8128$ & 0,2779 & $-0,7442$ \\
\hline $\begin{array}{l}\text { Nuclear } \\
\text { energy }\end{array}$ & - & $-0,2352$ & $-0,2670$ & $-0,2221$ & $-0,3240$ & $-0,3427$ & $-0,9635$ \\
\hline
\end{tabular}

Source: Calculation from Eurostat database (2018)

The gray colors show the correlation values that can be considered. The tones indicate the strength of relationship.

Concerning the results, it should be noted that the non-renewable energy sources were clearly separated, but the renewables were examined as a whole. Regarding the composition, the renewables can differ significantly by country. Biomass was the dominant renewable energy type in each country. However, some member states had other renewable sources with higher rates than the EU average (e.g. wind in Poland, biogas in the Czech Republic, or hydropower in Slovakia, Romania and Bulgaria).

\section{CONCLUSION}

The paper provides a comprehensive view on the energy situation of six Central European countries with special emphasis on the renewables. There is a very clear picture of high import energy dependency of these countries. The research presents original results of the relationship between renewable energy and non-renewable energy sources, as well as draws proper conclusions for practice.

The structure of energy production in the six Central European countries were different due to the differences of natural endowments. However, the results showed that renewables mainly replaced coal. The six countries were highly dependent on oil and natural gas. The main goal is to reduce the consumption of fossil energy and to replace them by renewables in the future. Reduction of oil consumption could be achieved by increasing consumption of biofuels and by using more electric or hybrid power devices. Natural gas used for heating can be replaced by biomass, solar, or geothermal energy. Coal, which is mainly responsible for environmental damage, can be replaced by biomass. In the case of electric power generation, coal can be replaced by hydropower, wind or solar energy. In addition to increasing the share of renewable energy, the EU also places emphasis on improvement of energy efficiency and/or savings. During the examined 
period, the decrease of energy consumption was affected not only by the negative impact of the 2008 crisis, but also by the spread of efficient consumers, for example, more energy-efficient motors, passive houses, modernization of light technics and so forth. Future studies may include more countries and a benchmark study based on the top performing countries regarding the use of renewable energy.

\section{REFERENCES}

British Patrol (2018). Statistical Review of World Energy. https://www.bp.com/en/global/corporate/e nergy-economics/statistical-review-ofworld-energy/downloads.html

Commission of the European Communities, (2006). Green Paper. A European Strategy for Sustainable, Competitive and Secure Energy. http://europa.eu/documents/comm/green_p apers/pdf/com2006_105_en.pdf Date of access: 10 October 2018.

Demirbas, M.F., Balat, M., Balat, H. (2009). Potential contribution of biomass to the sustainable energy development. Energy Conversion and Management, 50(7): 17461760.

https://doi.org/10.1016/j.enconman.2009.03 .013

Doner, J. (2007). Barriers to adoption of renewable energy technology. Illinois State University. Institute for Regulatory Policy Studies; p. 32

Ellabban, O., Abu-Rub, H., Blaabjerg, F. (2014). Renewable energy resources: Current status, future prospects and their enabling technology. Renewable and Sustainable Energy Reviews, 39: 748-764. https://doi.org/10.1016/j.rser.2014.07.113

European Commission, (1997). Communication from the Commission energy for the future: renewable sources of energy. Zhite Paper for a Community Strategy and Action Plan. http://europa.eu/documents/comm/white_p apers/pdf/com97_599_en.pdf Date of access: 10 October 2018.

Fodor, B. E. (2012). Promoting the Use of Renewable Energies. An Evaluation of the Hungarian Feed-in Tariff System. PhD
Dissertation. Corvinus University of Budapest p. 230.

Harangi - Rákos, M., Popp, J., Oláh, J. (2017). Global Outlook of World Biofuels Production. Journal of Central European Green Innovation. http://greeneconomy.unieszterhazy.hu/sites /greeneconomy.foiskola.krf/files/upload/JCE GI_2017_5_4_2.pdf Date of access: 14 November 2018.

Hernández, L., Burriel, J. R., Bujdosó, Z., Topliceanu, L. (2017). Training needs in renewable energies for local development. http://repositori.uji.es/xmlui/bitstream/han dle/10234/167300/02_Training\%20needs\%2 0in\%20RES\%20for\%20local\%20development En.pdf?sequence $=4$ Date of access: 18 November 2018.

International Energy Agency (2011). Deploying renewables 2011: Best and Future Policy Practice. p. 186 https://webstore.iea.org/deployingrenewables-2011-best-and-future-policypractice

Jurcova, V. (2017). The Slovak energy transition - decarbonization and energy security. https://energytransition.org/2017/05/theslovak-energy-transition-decarbonisationand-energy-security/

Piwowar, A., Olanszka, A., Rezny, L. (2017). Development of Renewable Energy in the Visegrad Ccountries - Comparative Analysis, in International Scientific Conference Hradec Economic Days 2017, At Hradec Králové, Czech Republic, pp. 695-705.

Popp, J. (2013). The role of bioenergy in the global energy supply. Gazdálkodás Scientific Journal. 57 (5): 419 - 435.

Popp, J., Oláh, J., Farkas Fekete, M., Lakner, Z., Máté, D. (2018a). The Relationship Between Prices of Various Metals, Oil and Scarcity. Energies, p. 1-19. https://doi.org/10.3390/en11092392, http://www.mdpi.com/19961073/11/9/2392

Popp, J., Kot, S., Lakner, Z., Oláh, J. (2018b). Biofuel use: peculiarities and implications. Journal of Security and Sustainability Issues, 7(3), p. 77-493. http://jssidoi.org/jssi/uploads/papers/27/Po 
pp_Biofuel_use_peculiarities_and_implicati ons.pdf

Reiche, D., Bechberger, M. (2004). Policy differences in the promotion of renewable energies in the EU member states. Energy Policy. 32(7): $843-849$.

REN21, (2018). Renewables 2018 Global Status Report 2018. http://www.ren21.net/wpcontent/uploads/2018/06/178652_GSR2018_FullReport_web_-1.pdf Date of access: 19 November 2018.

Szabo, M., Kiss, Á. (2014). Effects of renewable energy resources on the landscape. Hungarian Geographical Bulletin, 63(1):516.

Wiuff, A., Sandholt, K., Marcus-Møller, C. (2006). Renewable energy technology deployment: barriers, challenges and opportunities, EA energy analyses for the IEA RETD implementing agreement.

\section{ABOUT THE AUTHORS}

Natanya Meyer, email: natanya.eyer@nwu.ac.za

Dr. habil. Róbert Magda is an associate professor, at Szent István University, Faculty of Economics and Social Sciences, Institute of Economics, Law and Methodology and an extraordinary associate professor at School of Management Sciences Faculty of Economic and Management Sciences, NorthWest University, South Africa. He has a PhD in Economic Science and a Habilitated Doctorate in Management and Business Administration. During his research activities he has gained insight into several fields of research, which include but are not limited to the following: the examination of land as a natural and economic resource; the economic potentials of rural areas; limited resources and sustainability.

Dr. Norbert Bozsik is a college professor at Eszterházy Károly University, Faculty of Economics and Social Sciences, Department of Management. He has a Phd Management and Business Administration from Szent István University. During his research activities he focused on several fields of research, which are the following: analysis of the European food trade, analysis of energy consumption of Visegrad countries, efficiency of agricultural production, labour productivity in the Hungarian food industry. In these research areas he published a series of publications with his colleagues and students, both in domestic and international periodicals, journals and books.

Dr. Natanya Meyer is a senior lecturer at North West University (South Africa) in the Faculty of Economic and Management Sciences. She completed her B. Com and Honours degree in Economics and Risk Management and thereafter her Master's degree in Development and Management and PhD in Entrepreneurship. Her research focuses on entrepreneurial and economic related topics with a focus on females, youth and the enabling environment. She is a reviewer, editorial board and scientific committee member for several national and international journals and has collaboration links with various Asian and east European universities. 